\title{
Language Curriculum Design and Socialisation
}


Full details of all our publications can be found on http://www.multilingualmatters.com, or by writing to Multilingual Matters, St Nicholas House, 31-34 High Street, Bristol BS1 2AW, UK. 


\title{
Language Curriculum Design and Socialisation
}

\author{
Peter Mickan
}

MULTILINGUAL MATTERS

Bristol • Buffalo • Toronto 


\section{To my family members for their support and reality checks}

Library of Congress Cataloging in Publication Data

A catalog record for this book is available from the Library of Congress.

Mickan, Peter, author.

Language Curriculum Design and Socialisation/Peter Mickan.

Includes bibliographical references.

1. Language arts (Early childhood)-Curricula. 2. Language arts (Early childhood)-Social aspects. 3. Curriculum planning-Social aspects. 4. Socialization. 5. English languageStudy and teaching (Early childhood)-Foreign speakers. I. Title.

LB1139.5.L35M53 2013

372.6-dc23 2012036453

British Library Cataloguing in Publication Data

A catalogue entry for this book is available from the British Library.

ISBN-13: 978-1-84769-830-8 (hbk)

ISBN-13: 978-1-84769-829-2 (pbk)

\section{Multilingual Matters}

UK: St Nicholas House, 31-34 High Street, Bristol BS1 2AW, UK.

USA: UTP, 2250 Military Road, Tonawanda, NY 14150, USA.

Canada: UTP, 5201 Dufferin Street, North York, Ontario M3H 5T8, Canada.

\section{Channel View Publications}

UK: St Nicholas House, 31-34 High Street, Bristol BS1 2AW, UK.

USA: UTP, 2250 Military Road, Tonawanda, NY 14150, USA.

Canada: UTP, 5201 Dufferin Street, North York, Ontario M3H 5T8, Canada.

Copyright (C) 2013 Peter Mickan.

All rights reserved. No part of this work may be reproduced in any form or by any means without permission in writing from the publisher.

The policy of Multilingual Matters/Channel View Publications is to use papers that are natural, renewable and recyclable products, made from wood grown in sustainable forests. In the manufacturing process of our books, and to further support our policy, preference is given to printers that have FSC and PEFC Chain of Custody certification. The FSC and/or PEFC logos will appear on those books where full certification has been granted to the printer concerned.

Typeset by R. J. Footring Ltd, Derby

Printed and bound in Great Britain by the MPG Books Group 
the process we are interested in is that of producing and understanding text in some context of situation, perhaps the most distinctive form of activity in the life of social man. Halliday and Hasan (1985: 14) 
